International Journal of Engineering \& Technology, $7(3)(2018)$ 1757-1761
International Journal of Engineering \& Technology
SPC
Website: www.sciencepubco.com/index.php/IJET
doi: $10.14419 /$ ijet. $v 73.15426$
Research paper

\title{
Integrated-reservoir-model-based critical oil rate correlation for vertical wells in thin oil rim reservoirs in the Niger Delta
}

\author{
Anietie Ndarake Okon ${ }^{1} *$, Dulu Appah ${ }^{2}$ \\ ${ }^{1}$ Department of Chemical and Petroleum Engineering, University of Uyo, Nigeria \\ ${ }^{2}$ Department of Gas Engineering, University of Port Harcourt, Nigeria \\ *Corresponding author E-mail: anietieokon@uniuyo.edu.ng
}

\begin{abstract}
Thin oil rim reservoirs are mostly characterized by development and production challenges; one of which is early water coning tendency. In the Niger Delta, most developed critical oil rate correlations to avert coning focused on conventional bottom-water drive reservoirs, while thin oil rim reservoirs received limited attention. Available correlations to estimate critical oil rate of thin oil rim reservoirs in Niger Delta are based on generic reservoir models, which does not consider the reservoir heterogeneity. Hence, it leaves these available correlations' predictions in doubt, considering the sensitive nature of developing thin oil rim reservoirs. Thus, a correlation for critical oil rate $\left(\mathrm{q}_{\mathrm{c}}\right)$ based on integrated reservoir model in the Niger Delta was develop for thin oil rim reservoirs using multivariable numerical optimization approach. The obtained result indicated that the developed correlation predicted 226.05 bbl/day compared to the actual Oilfield critical oil rate of $226.11 \mathrm{bbl} / \mathrm{day}$. Furthermore, sensitivity study indicated that the developed correlation and the integrated reservoir model predictions of fractional well penetration $\left(\mathrm{h}_{\mathrm{p}} / \mathrm{h}\right)$ and height below perforation - oil column $\left(\mathrm{h}_{\mathrm{bp}} / \mathrm{h}\right)$ on critical oil rate $\left(\mathrm{q}_{\mathrm{c}}\right)$ were close and resulted in coefficient of determination $\left(\mathrm{R}^{2}\right)$ of 0.9266 and 0.9525 , Chi square $\left(X^{2}\right)$ of 0.539 and 0.655 , and RMSE of 4.336 and 4.357. Additionally, the results depict that critical oil rate depends indirectly on fractional well penetration and directly on height above perforation for vertical wells. Therefore, to delay water-coning tendency in thin oil rim reservoirs these completion parameters are consideration in vertical wells to establish optimum critical oil rate during hydrocarbons production. Also, the developed correlation can be used as a quick tool to estimate critical oil rate of thin oil rim reservoirs in the Niger Delta.
\end{abstract}

Keywords: Water Coning; Critical Oil Rate; Integrated Reservoir Model; Thin Oil Rim Reservoir; Niger Delta.

\section{Introduction}

In the production of oil and gas from petroleum reservoirs, one of the recurrent problems that associates with and will continue to, is water production. This produced water in most cases is as a result of normal rise of oil water contact, water coning, water fingering, water channeling or a combination [1-3]. In bottom water drive reservoirs, excessive water production cannot be undermined, as the aforementioned phenomena would result in water handling problems at the surface, low hydrocarbon recovery, serious economic and environmental problems [3-4]. Therefore, adequate production strategies are put in place to avert these recurrent production-related-problems. Water coning or cusping - depending on the direction of the encroached water, is one of the problems. The encroached water into the wellbore is usually due to the density difference between the fluids: oil and water [5]. Just like conventional reservoirs with strong bottom water drive, oil production from thin oil rim reservoirs has always been a challenge due to thiny spread oil resources and complicated production mechanism [6]. Coning phenomenon in thin oil rim reservoirs is common because of their thin oil columns; especially when it is sandwiched between overlaid gas cap and underlain water aquifer. Existing literature indicated that several water coning correlation and control methods had been developed to predict and/or mitigate the severity of water coning phenomenon during hydrocarbon produc- tion. The developed water coning correlations include critical oil rate $\left(\mathrm{q}_{\mathrm{c}}\right)$; that is, the maximum production oil rate without producing water, breakthrough time $\left(\mathrm{tbt}_{\mathrm{t}}\right)$ - time water enters the wellbore, and post water performance after breakthrough [7]. Osisanya et al. [8] maintained that critical oil rate $\left(\mathrm{q}_{\mathrm{c}}\right)$ is the most discussed coning correlation. In the Niger Delta, water-coning phenomenon in thin oil rim reservoirs has received some attention in the works of Omeke et al. [9], Onwukwe [5], Onwukwe et al. [10], Abdulkarim [11], etc. Regrettably, these studies used generic reservoir models, design of experiment and/or response surface approach to develop coning parameters correlation for thin oil rim reservoirs. Consequently, this approach does not consider the heterogeneity nature of the reservoirs. Hence, it leaves these available correlations in doubt, considering the sensitive nature of thin oil rim reservoirs [12-13]. Besides, there are correlations based on data obtained from other oil producing regions of the World. However, the varying geology of the formation, fluid and other factors make the existing coning correlations prediction for Niger Delta thin oil rim reservoirs less accurate [11]. Therefore, it becomes important to develop water coning parameters correlation based on data and integrated reservoir model from the Niger Delta thin oil rim reservoirs to enhance the reliability of the correlation's prediction. In this study, critical oil rate correlation based on production history from existing thin oil rim reservoir in ADX Oilfield in the Niger Delta was develop. The developed correlation performance was validated with the field's integrated reservoir model. 


\section{Critical oil rate correlation development}

In the literature, Hoyland et al. [14] and Recham et al. [15] had developed critical oil rate $\left(\mathrm{q}_{\mathrm{c}}\right)$ correlations from numerical approach. These correlations basically comprises of the fluid density difference $(\Delta \rho)$, fractional well penetration $\left(h_{p} / h\right)$, horizontal permeability $\left(\mathrm{kh}_{\mathrm{h}}\right)$, oil column $(\mathrm{h})$ and drainage radius $\left(\mathrm{r}_{\mathrm{e}}\right)$. On the other hand, Recham et al. [15] added oil viscosity $\left(\mu_{\mathrm{o}}\right)$, oil formation volume factor $\left(\mathrm{B}_{\mathrm{o}}\right)$ and dimensionless critical rate $\left(q_{c_{p}}\right)$ to the aforementioned parameters. The dimensionless critical rate $\left(q_{c_{D}}\right)$ contains mobility ration $(\mathrm{M})$, anisotropy $\left(\mathrm{k}_{\mathrm{v}} / \mathrm{kh}_{\mathrm{h}}\right)$, height above perforation - oil column $\left(\mathrm{h}_{\mathrm{ap}} / \mathrm{h}\right)$ and height below perforation - oil column $\left(\mathrm{h}_{\mathrm{bp}} / \mathrm{h}\right)$ terms. Hence, the Hoyland et al. [14] and Recham et al. [15] correlations are expanded in Equations 1 and 2, respectively.

$$
\begin{aligned}
& q_{c}=\frac{\Delta \rho k_{h}}{10,822}\left[1-\left(\frac{h_{p}}{h}\right)^{2}\right]^{1.325}(h)^{2.238}\left[\ln \left(r_{e}\right)\right]^{-1.900} \\
& q_{c}=\frac{\Delta \rho h^{2} k_{h}}{651.4 \mu_{o} B_{o}} q_{c_{D}}
\end{aligned}
$$

Where $q_{c_{p}}$ expression is given in Equation 3;

$$
q_{c_{D}}=\left[\frac{8.32 \times 10^{-4}\left(r_{e_{p}}\right)^{0.76}\left(1+M^{-0.78}\right)\left(1-\frac{h_{p}}{h}\right)\left(1-\frac{h_{b p}}{h}\right)}{\left(\frac{h-h_{p}-h_{a p}}{h_{b p}-1}\right)^{2}-1}\right]
$$

$$
\text { Then } \mathrm{M} \text { is given as } M=\frac{\mu_{o} k_{m}}{\mu_{w} k_{m}} \text { and } r_{e_{D}} \text { is expressed as } r_{r_{p}}=\frac{r_{c}}{h} \sqrt{\frac{k_{v}}{k_{h}}} \text {. }
$$

For the development of the proposed critical oil rate correlation for the ADX Oilfield in the Niger Delta, the following parameters, namely, oil-water density difference $\left(\Delta \rho_{\mathrm{ow}}\right)$, oil viscosity $\left(\mu_{\mathrm{o}}\right)$, oil formation volume factor $\left(\mathrm{B}_{\mathrm{o}}\right)$, horizontal permeability $\left(\mathrm{k}_{\mathrm{h}}\right)$, anisotropy $\left(\mathrm{k}_{\mathrm{v}} / \mathrm{k}_{\mathrm{h}}\right)$, oil column $(\mathrm{h})$, fractional well penetration $\left(\mathrm{h}_{\mathrm{p}} / \mathrm{h}\right)$, height below perforation - oil column $\left(\mathrm{h}_{\mathrm{bp}} / \mathrm{h}\right)$ and drainage radius wellbore radius $\left(\ln \left(\mathrm{r}_{\mathrm{e}} / \mathrm{r}_{\mathrm{w}}\right)\right)$ were considered. In other words, the critical oil rate is expressed as a function of the mentioned parameters in Equation 4;

$$
q_{c}=f\left[\Delta \rho_{o w}, \mu_{o}, B_{o}, k_{h}, h,\left(k_{v} / k_{h}\right),\left(h_{p} / h\right),\left(h_{b p} / h\right), \ln \left(r_{c} / r_{w}\right)\right]
$$

Generally, water coning - upward movement of water, occurs when the viscous forces around the wellbore exceed gravity forces due to density difference between the fluids: oil and water [5]. The viscous force $\left(\Delta \mathrm{P}_{\mathrm{v}}\right)$ and gravity force $\left(\Delta \mathrm{P}_{\mathrm{g}}\right)$ are expressed in Equations 5 and 6 , respectively.

$\Delta P_{v}=\frac{q_{o} \mu_{o} B_{o} \ln \left(r_{e} / r_{w}\right)}{k_{o} h}$

$\Delta P_{g}=g \Delta \rho h$

Then, the optimum oil production rate (critical oil rate, QC) occurs when the viscous and the gravity forces are at equilibrium in the wellbore; that is, $\Delta \mathrm{P}_{\mathrm{v}}$ equals $\Delta \mathrm{P}_{\mathrm{g}}$. Therefore, the critical oil rate can be expanded as Equation 7.

$$
q_{c}=\frac{g \Delta \rho k h^{2}}{u_{o} B_{o} \ln \left(r_{e} / r_{w}\right)}
$$

From this Equation 7, the critical oil rate depends directly on some parameters and inversely on others. Based on this assertion, the parameters in Equation 4 are expressed (Equations 8 and 9) as the critical oil rate $\left(\mathrm{q}_{\mathrm{c}}\right)$ related to them.

$$
\left.\begin{array}{l}
q_{c} \propto \Delta \rho_{o w} \\
q_{c} \propto h \\
q_{c} \propto k_{h} \\
q_{c} \propto\left(k_{v} / k_{h}\right) \\
q_{c} \propto\left(h_{p} / h\right) \\
q_{c} \propto\left(h_{b p} / h\right)
\end{array}\right\}
$$

$$
\left.\begin{array}{l}
q_{c} \propto \frac{1}{\mu_{o}} \\
q_{c} \propto \frac{1}{B_{o}} \\
\left.q_{c} \propto \frac{1}{\ln \left(r_{c} / r_{w}\right)}\right)
\end{array}\right\}
$$

Hence, the Equation 4 becomes

$q_{c}=f\left[\frac{\Delta \rho_{o w}, k_{h}, h,\left(k_{v} / k_{h}\right),\left(h_{p} / h\right),\left(h_{b p} / h\right)}{\mu_{o}, B_{o}, \ln \left(r_{e} / r_{w}\right)}\right]$

The obtained Equation 10 can be presented in the basic form of nonlinear multivariable algebraic form; as in Equation 11 [16]. This Equation 11 can further be expanded in a linear form using logarithmic transformation and presented in Equation 12;

$q_{c}=b_{o}\left[\frac{\left(\Delta \rho_{o w}\right)^{\beta_{1}} h^{\beta_{2}} k_{h}^{\beta_{3}}\left(k_{v} / k_{h}\right)^{\beta_{s}}\left(1-h_{p} / h\right)^{\beta_{s}}\left(h_{b p} / h\right)^{\beta_{o}}}{\mu_{o}^{\beta_{3}} B_{o}^{\beta_{s}}\left[\ln \left(r_{c} / r_{w}\right)\right]^{\beta_{s}}}\right]$

$\log \left(q_{c}\right)=\log \left(b_{o}\right)+\beta_{1} \log \left(\Delta \rho_{\text {ov }}\right)+\beta_{2} \log (h)+\beta_{3} \log \left(k_{h}\right)+\beta_{4} \log \left(k_{v} / k_{h}\right)+\beta_{5} \log \left(1-h_{p} / h\right)+$

$\beta_{6} \log \left(h_{b p} / h\right)-\beta_{7} \log \left(\mu_{o}\right)-\beta_{8} \log \left(B_{o}\right)-\beta_{9} \log \left[\ln \left(r_{c} / r_{w}\right)\right]$

Where $b_{o}$ is coefficient (i.e., proportionality constant) and $\beta_{1}$ through $\beta_{9}$ are exponential constants for the critical oil variables. In the Equation 12, the $b_{o}$ and coefficients $\beta_{1}$ through $\beta_{9}$ were determined iteratively using multivariable numerical optimization. In the literature, there are several approaches to perform this iterative estimation, namely, Gauss-Newton, the MarquardtLevenberg, the Nelder-Mead, the steepest descent, etc. [17-19]. Okon et al. [12] mentioned that there is a robust and reliable Solver in Microsoft Excel, which uses General Reduced Gradient (GRG) as the iterative algorithm that can be used to perform multivariable numerical solution. Thence, the reservoir, fluid and well completion parameters required to determine the coefficient (bo) and exponential constants $\left(\beta_{1}\right.$ through $\left.\beta_{9}\right)$ in the Equation 11 were obtained from the ADX Oilfield production data (Table 1). Based on the presented parameters' values in Table 1, the unknown coefficient $\left(b_{0}\right)$ and exponential constants $\left(\beta_{1}\right.$ through $\left.\beta_{9}\right)$ in Equation 11 were determine iteratively using the GRG algorithm in Microsoft Excel Solver. 
Table 1: Basic ADX Oilfield Reservoir, Fluid and Completion Data

\begin{tabular}{llll}
\hline Parameters & Value & Parameters & Value \\
\hline $\begin{array}{l}\text { Oil Viscosity }\left(\mu_{\mathrm{o}}\right), \\
\mathrm{cP}\end{array}$ & 0.972 & Oil Density $\left(\rho_{\mathrm{o}}\right), \mathrm{lb} / \mathrm{ft}^{3}$ & 53.563 \\
$\begin{array}{l}\text { Wellbore Radius } \\
\left(\mathrm{r}_{\mathrm{w}}\right), \mathrm{ft}\end{array}$ & 0.216 & Water Density $\left(\rho_{\mathrm{w}}\right), \mathrm{lb} / \mathrm{ft}^{3}$ & 64.114 \\
$\begin{array}{l}\text { Water Viscosity } \\
\left(\mu_{\mathrm{w}}\right), \mathrm{cP}\end{array}$ & 0.246 & $\begin{array}{l}\text { Oil Formation Volume Factor } \\
\left(\mathrm{B}_{\mathrm{o}}\right), \mathrm{rb} / \mathrm{stb}\end{array}$ & 1.119 \\
$\begin{array}{l}\text { Oil Column }(\mathrm{h}), \mathrm{ft} \\
\text { Completion Interval } \\
\left(\mathrm{h}_{\mathrm{p}}\right), \mathrm{ft}\end{array}$ & 85.0 & $\begin{array}{l}\text { Vertical Permeability }\left(\mathrm{k}_{\mathrm{v}}\right), \mathrm{mD} \\
\text { Horizontal Permeability }\left(\mathrm{k}_{\mathrm{h}}\right),\end{array}$ & 2.0074 \\
$\begin{array}{l}\text { Drainage Radius }\left(\mathrm{r}_{\mathrm{e}}\right), \\
\mathrm{ft}\end{array}$ & 29.50 & $\begin{array}{l}\text { mD } \\
\text { Height below Perforation } \\
\text { Interval }\left(\mathrm{h}_{\mathrm{bp}}\right), \mathrm{ft}\end{array}$ & 70.55 \\
\hline
\end{tabular}

The obtained coefficient $\left(b_{o}\right)$ and exponential constants $\left(\beta_{1}\right.$ through $\beta_{9}$ ) for the critical oil rate correlation are presented in Table 3. From this, the developed critical oil rate correlation is expanded in Equation 14. Then, the developed correlation was validated by comparing its prediction alongside with other authors: Hoyland et al. [14] and Recham et al. [15] correlations with the actual ADX Oilfield critical oil rate; as obtained from the production history data. Also, sensitivity studies of the completion interval parameters: fractional well penetration $\left(h_{\mathrm{p}} / \mathrm{h}\right)$ and height below perforation - oil column $\left(\mathrm{h}_{\mathrm{bp}} / \mathrm{h}\right)$ on the critical oil rate $\left(\mathrm{q}_{\mathrm{c}}\right)$ were performed using the ADX reservoir model (Figure 1). The sensitivity studies were based on the values provided in Table 2 . The obtained simulated results were compared with the developed critical oil rate and other authors' correlations prediction. These results are depicted (Figures 3 and 4). Furthermore, statistical tools: coefficient of determination $\left(\mathrm{R}^{2}\right)$, Chi square $\left(X^{2}\right)$ and root mean square error (RMSE); as expanded in Equations 13 through 15 , were used to establish the closeness of the developed correlation prediction to the obtained reservoir model simulation results. The obtained results are presented in Table 4.

Table 2: Values for Critical Oil Rate Sensitivity Studies

\begin{tabular}{lll}
\hline & Parameters & Values \\
\hline \multirow{2}{*}{ i. } & Fractional Well Penetration $\left(\mathrm{h}_{\mathrm{p}} / \mathrm{h}\right)$ & $0.2,0.3,0.4,0.5$, \\
& & 0.6 \\
ii. & Height below Perforation - Oil Column & $0.1,0.2,0.3,0.4$, \\
& $\left(\mathrm{h}_{\mathrm{bp}} / \mathrm{h}\right)$ & 0.5 \\
\hline
\end{tabular}

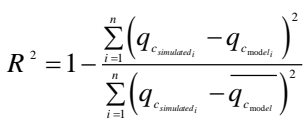

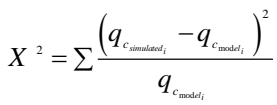

$R M S E=\sqrt{\frac{\sum_{i=1}^{N}\left(q_{c_{\text {simularati }_{i}}}-q_{c_{\text {madedi }}}\right)^{2}}{N}}$

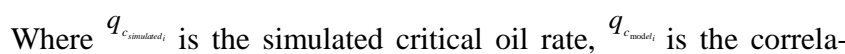
tion predicted critical oil rate and $\overline{q_{c_{\operatorname{mad}}}}$ is the average correlation predicted critical oil rate.
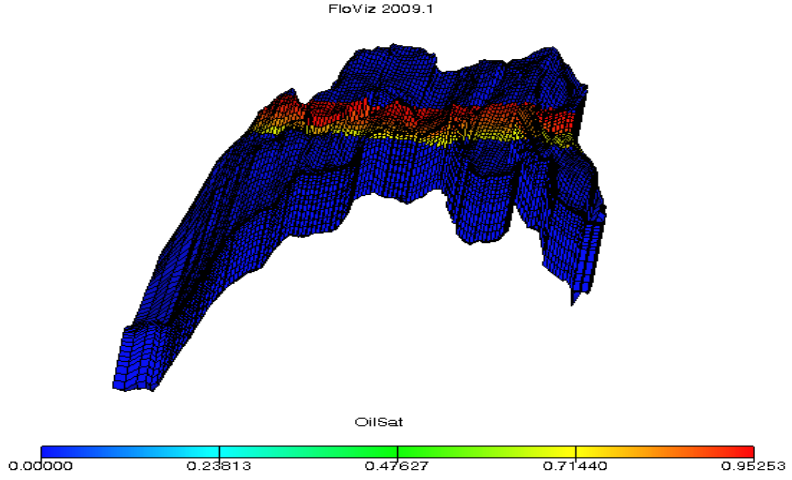

Fig. 1: Reservoir Model of ADX Oilfield in the Niger Delta.

\section{Developed critical oil rate correlation}

From the performed multivariable numerical optimization, the determined coefficient $\left(b_{0}\right)$ and exponential constants $\left(\beta_{1}\right.$ through $\beta_{9}$ ) for the critical oil rate correlation are presented in Table 3. Based on these values in Table 3, the developed critical oil rate correlation for the ADX Oilfield is presented in Equation 16. This Equation 16 predicted critical oil rate of $226.05 \mathrm{bbl} / \mathrm{day}$; based on the ADX Oilfield data. The prediction by this developed correlation is comparable to the actual ADX Oilfield critical oil rate of $226.11 \mathrm{bbl} /$ day; as indicated in Figure 2. Note, in Figure 2, this actual critical oil rate $\left(\mathrm{q}_{\mathrm{c}}\right)$ is the highest (apex) oil production rate at which the water-cut begins to increase, thus, indicating water breakthrough. Other authors': Hoyland et al. [14] and Recham et al. [15] correlations predicted critical oil rate of $33.76 \mathrm{bbl} /$ day and $75.19 \mathrm{bbl} /$ day respectively, for the ADX Oilfield. These authors' correlation predictions were far less than the actual critical oil rate of the ADX Oilfield in the Niger Delta. Based on the correlations' predictions comparison with the ADX Oilfield production data, it is obvious that the developed critical oil rate correlation (i.e., Equation 16) gives a more realistic prediction of the ADX. Oilfield critical oil rate than the other authors correlations.

Table 3: Coefficients for Critical Oil Rate Correlation (Equation 16)

\begin{tabular}{llll}
\hline & Parameters & Coefficients & Values \\
\hline i. & Proportionality Constant & $\mathrm{b}_{\mathrm{o}}$ & 86 \\
ii. & Oil-water Density difference, $(\Delta \rho)$ & $\beta_{1}$ & 0.1872 \\
iii. & Vertical Permeability, $\mathrm{k}_{\mathrm{v}}$ & $\beta_{2}$ & 0.1941 \\
iv. & Oil Column, $\mathrm{h}$ & $\beta_{3}$ & 0.1709 \\
v. & Anisotropy Ratio, $\left(\mathrm{k}_{\mathrm{v}} / \mathrm{k}_{\mathrm{h}}\right)$ & $\beta_{4}$ & 0.1994 \\
vi. & Fractional Well Penetration, $\left(\mathrm{h}_{\mathrm{p}} / \mathrm{h}\right)$ & $\beta_{5}$ & 0.1800 \\
vii. & Height below Perforation-Oil Column, & $\beta_{6}$ & 0.2025 \\
viii. & $\left(\mathrm{h}_{\mathrm{bp}} / \mathrm{h}\right)$ & $\beta_{7}$ & 0.1996 \\
ix. & Oil Viscosity, $\left(\mu_{\mathrm{o}}\right)$ & $\beta_{8}$ & 0.1722 \\
x. & Drainage Radius - Wellbore Radius, & $\beta_{9}$ & 0.2018 \\
\hline
\end{tabular}

$q_{c}=86\left[\frac{\Delta \rho_{o w}^{0.1872} k_{h}^{0.1941} h^{0.1709}\left(k_{v} / k_{h}\right)^{0.1994}\left(1-h_{p} / h\right)^{0.18}\left(h_{b p} / h\right)^{0.2025}}{\mu_{o}^{0.1996} B_{o}^{0.1722}\left\{\ln \left(r_{c} / r_{w}\right)\right\}^{0.2018}}\right]$



Fig. 2: Oil Production Rate and Water-Cut History of the ADX Oilfield 
On the other hand, the sensitivity studies results of the completion interval ratios: fractional well penetration $\left(h_{p} / h\right)$ and height below perforation - oil column $\left(\mathrm{h}_{\mathrm{bp}} / \mathrm{h}\right)$ on critical oil rate $\left(\mathrm{q}_{\mathrm{c}}\right)$ are presented in Figures 3 and 4. Again, the obtained results indicated that the developed critical oil rate $\left(\mathrm{q}_{\mathrm{c}}\right)$ correlation (Equation 14) predictions were close to the obtained simulation results from the ADX Oilfield reservoir model. These predictions from the developed correlation and ADX reservoir model resulted in coefficient of determination $\left(\mathrm{R}^{2}\right)$ of 0.9266 and 0.9525 , Chi square $\left(X^{2}\right)$ of 0.539 and 0.655 , and RMSE of 4.336 and 4.357 for fractional well penetration $\left(h_{p} / h\right)$ and height below perforation - oil column $\left(h_{b p} / h\right)$, respectively. These obtained statistical analysis results implied that the developed critical oil rate $\left(\mathrm{q}_{\mathrm{c}}\right)$ would be use to predict the ADX Oilfield critical oil rate to avert water coning tendency during oil production. The predictions from Hoyland et al. [14] and Recham et al. [15] correlations in the sensitivity studies were far less than the obtained reservoir simulation results, as depicted in Figures 3 and 4 . This observation would be attributed to the quantity and scope of data upon which these correlations were based [13]. Thus, the data upon which these correlations are based were from generic reservoir models not integrated field reservoir model. In addition to the aforementioned, the relation of the reservoir and well completion interval parameters to the critical oil rate are considerable factors. Hoyland et al. [14] neglects oil viscosity $\left(\mu_{\mathrm{o}}\right)$, oil formation volume factor $\left(B_{o}\right)$, wellbore radius $\left(r_{w}\right)$ and height below perforation - oil column $\left(h_{b p} / h\right)$ in their correlation. Some of these parameters are pertinent in equation that express oil production rate (q); as depicted in Equation 7. On the other hand, Recham et al [15] included these mentioned parameters in their correlation. However, the relation of the height below perforation - oil column $(\mathrm{hbh} / \mathrm{h})$ in the correlation was not considered as direct dependent on the oil production rate, rather it was presented as (1$\mathrm{h}_{\mathrm{bp}} / \mathrm{h}$ ). This expression in Recham et al. [15] correlation shows the obtained result for height below perforation - oil column $\left(h_{b p} / h\right)$ sensitivity on critical oil rate $\left(\mathrm{q}_{\mathrm{c}}\right)$ to be on the decrease instead of the increase as obtained from the reservoir model simulation runs and the developed correlation (Figure 4). In all, the close predictions of the ADX Oilfield's critical oil rate(s) by the developed critical correlation makes it a robust and quick tool to predict critical oil rate of the thin oil rim reservoir(s) in the Niger Delta than the other correlations.

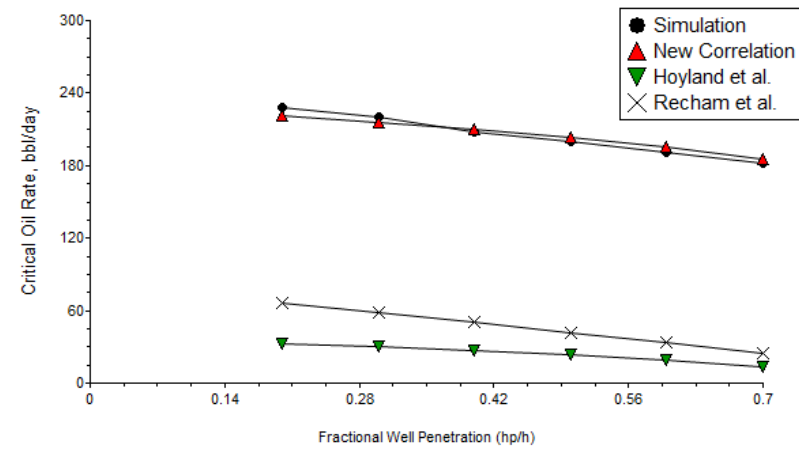

Fig. 3: Critical Oil Rate $\left(\mathrm{q}_{\mathrm{C}}\right)$ against Fractional Well Penetration $\left(\mathrm{h}_{\mathrm{p}} / \mathrm{h}\right)$

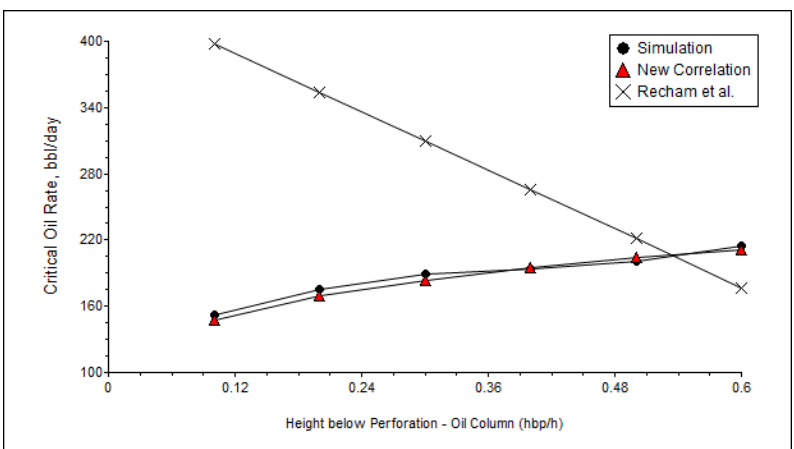

Fig. 4: Critical Oil Rate $\left(\mathrm{q}_{\mathrm{C}}\right)$ against Height below Perforation - Oil Column $\left(\mathrm{h}_{\mathrm{bp}} / \mathrm{h}\right)$.
Table 4: Statistical Comparison of the Developed Correlation and Reservoir Model Predictions from the Sensitivity Study

\begin{tabular}{lllll}
\hline & $\begin{array}{l}\text { Completion Pa- } \\
\text { rameter }\end{array}$ & $\begin{array}{l}\text { Coefficient of } \\
\text { Determination } \\
\left(\mathrm{R}^{2}\right)\end{array}$ & $\begin{array}{l}\text { Chi } \\
\text { Square } \\
\text { Values } \\
\left(X^{2}\right)\end{array}$ & $\begin{array}{l}\text { Root Mean } \\
\text { Square Error } \\
(\text { RMSE) }\end{array}$ \\
\hline i & $\begin{array}{l}\text { Fractional well } \\
\text { penetration, }\left(\mathrm{h}_{\mathrm{p}} / \mathrm{h}\right)\end{array}$ & 0.9266 & 0.539 & 4.336 \\
$\mathrm{ii}$ & $\begin{array}{l}\text { Height below } \\
\text { perforation }- \text { oil } \\
\text { column, }\left(\mathrm{h}_{\mathrm{bp}} / \mathrm{h}\right)\end{array}$ & 0.9525 & 0.655 & 4.357 \\
\hline
\end{tabular}

\section{Conclusion}

The Niger Delta like other oil producing regions of the world has several thin oil column reservoirs with promising reserves. Developing these reservoirs pose serious production challenges due its thiny spread resources. One of the pronounced challenges is the early coning of water into the wellbore. Hence, the prediction of these reservoirs' critical oil rate - water free oil production rate is important. Regrettably, available correlations' predictions for Niger Delta thin oil rim reservoirs are skeptical, as the correlations were developed based on generic reservoir models or data obtained from other oil producing regions of the world. Therefore, this study developed critical oil rate correlation based on integrated reservoir model for thin oil rim reservoirs in the Niger Delta. Thus, the following conclusions are drawn:

i) the developed correlation prediction and the actual Oilfield critical oil rate were comparable, that is, 226.05 $\mathrm{bbl} /$ day and $226.11 \mathrm{bbl} /$ day;

ii) for the critical oil rate $\left(\mathrm{q}_{\mathrm{c}}\right)$, the developed correlation and the integrated reservoir model sensitivity predictions were close and resulted in coefficient of determination $\left(\mathrm{R}^{2}\right)$ of 0.9266 and 0.9525 , Chi square $\left(X^{2}\right)$ of 0.539 and 0.655 , and RMSE of 4.336 and 4.357 for fractional well penetration $\left(h_{\mathrm{p}} / \mathrm{h}\right)$ and height below perforation - oil column $\left(h_{b p} / h\right)$, respectively; and

iii) in vertical wells, critical oil rate $\left(\mathrm{q}_{\mathrm{C}}\right)$ depends indirectly on fractional well penetration $\left(\mathrm{h}_{\mathrm{p}} / \mathrm{h}\right)$ and directly on height above perforation $\left(h_{b p}\right)$.

Thus, for thin oil rim reservoirs in the Niger Delta fractional well penetration and height below perforation are considerable factors to achieve optimum critical oil rate while averting early water breakthrough. The developed correlation can be used as a quick tool for estimation of critical oil rate for thin oil rim reservoirs in the Niger Delta.

$$
\begin{aligned}
& \text { Nomenclature } \\
& q_{c}=\text { critical rate, } s t b / d \\
& \Delta \rho_{o w}=\text { water-oil density difference, } l b / f t^{3} \\
& \mu_{o}=\text { oil viscosity, } c p \\
& \mu_{w}=\text { water viscosity, } c p \\
& r_{w}=\text { wellbore radius, } f t \\
& r_{e}=\text { drainage radius, } f t \\
& h=\text { oil column, } f t \\
& h_{p}=\text { height of completion interval, } f t \\
& k_{v}=\text { vertical permeability, } m d \\
& k_{h}=\text { horizontal permeability, md } \\
& B_{o}=\text { oil formation volume factor, } r b / s t b \\
& M=\text { mobility ratio } \\
& g=\text { gravity constant, } f t / h r^{2} \\
& h_{a p}=\text { height above perforation, } f t \\
& h_{b p}=\text { height below perforation, } f t
\end{aligned}
$$


$q_{o}=$ oil production rate $s t b / d$

$q_{c_{D}}=$ dimensionless critical rate

$r_{e D}=$ dimensionless drainage radius

$\Delta P_{v}=$ pressure drawdown due to viscous effects, $p s i$

$\Delta P_{g}=$ pressure drawdown due to gravity forces, $p s i$

$k_{r o}=$ oil relative permeability at $S_{w c}$

$k_{r w}=$ water relative permeability at $S_{o r}$

$S_{w c}=$ connate water saturation

$S_{o r}=$ residual oil saturation

\section{References}

[1] S.M. Saad, T. Darwich, Y. Asaad, Water coning in fractured basement reservoirs. Paper presented at Society of Petroleum Engineers Middle East Oil Show, Bahrain, 11-14 March, (1995) 1-10. https://doi.org/10.2118/29808-MS

[2] K.B. Ayeni, Empirical modeling and simulation of edgewater cusping and coning. PhD. Dissertation, Texas A\&M University, USA. (2008).

[3] A.N. Okon, D. Appah, J.U. Akpabio, A critical evaluation of water coning correlations in vertical wells. American Journal of Science, Engineering and Technology, Vol. 3, No. 1, (2018) 1-9.

[4] M. Mahgoup, E. Khair, Excessive water production diagnostic and control - case study of Jake oil field - Sudan. International Journal of Sciences: Basic and Applied Research, Vol. 23, No. 2, (2015) 81-94.

[5] S.I. Onwukwe, A novel approach for estimating critical rate and horizontal well placement in oil rim reservoirs. Unpublished PhD Thesis, Federal University of Technology, Owerri, Nigeria. (2011).

[6] O. Mogbo, Intelligent wells: oil rims abundant in the Niger Delta a case study. Paper presented at the Trinidad and Tobago Energy Resources Conference held in Port of Spain, Trinidad, 27-30 June, (2010) 1-8. https://doi.org/10.2118/133389-MS.

[7] A.N. Okon, D. Appah, J.U. Akpabio, Water coning prediction review and control: developing an integrated approach. Journal of Scientific Research and Reports, Vol. 14, No. 4, (2017) 1-24. https://doi.org/10.9734/JSRR/2017/33291.

[8] S.O. Osisanya, B. Recham, M. Touami, Effects of water coning on the performance of vertical and horizontal wells - a reservoir simulation study of Hassi R' Mel Field, Algeria. Paper presented at the Canadian International Petroleum Conference, Calgary, Alberta, Canada, 4-8 June, (2000).

[9] J.E. Omeke, A. Livinus, I.N. Uche, B. Obah, E. Ekeoma, A proposed cone breakthrough time model for horizontal wells in thin oil rim reservoirs. Paper presented at the 34th Annual Society of Petroleum Engineers International Conference and Exhibition, Tinapa, Calabar, Nigeria, 31 July-7 August, (2010) 1-11. https://doi.org/10.2118/140743-MS.

[10] S.I. Onwukwe, B. Obah, G.A Chukwu, A model approach of controlling coning in oil rim reservoirs. Paper presented at the Nigerian Annual Technical Conference and Exhibition of Society of Petroleum Engineers, Abuja, 6-8 August, (2012) 1-10. https://doi.org/10.2118/163039-MS.

[11] M.A. Abdulkarim, Development of coning correlations for oil rim reservoirs using experimental design and response surface methodology. Unpublished M.Sc. Thesis, African University of Science and Technology, Abuja, Nigeria. (2014)

[12] A.N. Okon, F.D. Udoh, D. Appah, Empirical wellhead pressure production rate correlations for Niger Delta oil wells. Paper presented at the Society of Petroleum Engineers Nigeria Annual International Conference and Exhibition, Lagos, Nigeria, 4-6 August, (2015) 1-17.

[13] A.N. Okon, D. Appah, Neural network models for predicting wellhead pressure - flow rate relationship for Niger Delta. Journal of Scientific Research and Reports, Vol. 12, No. 1, (2016). 1-14. https://doi.org/10.9734/JSRR/2016/28715.

[14] L.A. Hoyland, P. Papatzacos, S.M. Skjaeveland, Critical rate for water coning: correlation and analytical solution. Paper presented at the Society of Petroleum Engineers European Petroleum Conference, London, 20-22 October, (1989) 1-8. https://doi.org/10.2118/15855-PA.
[15] R. Recham, S.O. Osisanya, M. Touami, Effect of Water coning on the performance of vertical and horizontal wells - a reservoir simulation study of Hassi R'mel field, Algeria. Paper presented at Society of Petroleum Engineers/Petroleum Society of Canadian Institute of Mining, Metallurgy and Petroleum International Conference on Horizontal Well Technology, Calgary, Alberta, Canada, 6-8 November, (2000) 1-12. https://doi.org/10.2118/65506-MS.

[16] A.K. Permadi, New empirical correlation for predicting water breakthrough time of a vertical well in a bottom-water reservoir. Jurnal Teknologi Mineral. https://petroleumstudies.files.wordpress.com/2009/03/11.pdf. Accessed 10 May 2017.

[17] J. Wei, Multivariate numerical optimization. Lecture note. (2013). https://studentportalen.uu.se/uusp-filearea-tool. Accessed: 1 June 2018.

[18] G.K. Smyth, Optimization and nonlinear equations. Wiley StataRef: Statistics Reference Online. (2015) 1-9. doi: 10.1002/9781118445112.stat05030.pub2. https://doi.org/10.1002/9781118445112.stat05030.pub2.

[19] M. Pashaie, M. Sadeghi A. Jafarian, Artificial neural networks with Nelder-Mead optimization method for solving nonlinear integral equations. Journal of Computer Science and Application, Vol. 8 , No. 1, (2016) 1-20. 